\title{
Environmental and economic evaluation of conventional and organic production systems in the Canadian Prairie provinces
}

\author{
S. Kulshreshtha ${ }^{1}$ \& C. Klemmer ${ }^{2}$ \\ ${ }^{1}$ Department of Bioresource Policy, Business and Economics, \\ University of Saskatchewan, Saskatoon, Canada \\ ${ }^{2}$ Farm Credit Corporation, Regina, Canada
}

\begin{abstract}
Changing agriculture current production practices (called conventional production system) to an organic production system can reduce the need for synthetically produced agricultural inputs, and thereby reduce emissions. However, this change may also generate other co-benefits (or costs) to society. The focus of this study is to evaluate the implications of converting a conventional agriculture production system to an organic one for greenhouse gas emissions, level of agricultural production, farmer net income, and for regional and national level changes. The analysis was undertaken for the three Prairie Provinces in Canada. Since there are several types of changes resulting from the conversion, a trade-off analysis was used to evaluate the overall desirability of the two production systems. The study concluded that converting land under a conventional production system to an organic production system reduces greenhouse gas emissions and improves farm income, Canadian gross domestic product, household income, and employment. However, it also results in a reduction in physical quantity of agricultural production, and thus has implications for food self-sufficiency.

Keywords: organic crop production, greenhouse gas emissions, farm income, sustainable food production, trade-offs.
\end{abstract}

\section{Introduction}

The impact of agriculture on the environment has come under increasing scrutiny (Hanley [1]). Over the past century, the climate on earth has become increasingly 
warm IPCC [2]. Greenhouse gas (GHG) emissions are commonly believed to be one of the major root causes of climate change. These emissions occur both naturally as well as a result of human activity. Burning of fossil fuels and the generation of hydrocarbons are greatly disrupting the carbon cycle (the movement and storage of carbon). The human consumption of oil and coal, as well as the destruction of forests in both the developed and developing worlds has both increased carbon in the atmosphere and reduced the planet's ability to sequester carbon.

Scientists and policymakers around the world have identified agriculture as one of the major contributors to the world's GHG emissions (Rosenberg et al. [3]). In Canada agriculture's contribution is estimated to be $62 \mathrm{Mt}$, equivalent to $8.4 \%$ of the total Canadian GHG emissions. This in not including transportation, input costs, or agri-food processing" Government of Canada [4].

Organic farming (used in this study as synonymous to Organic Production System or OPS) is defined as a "system of managing agricultural holdings that implies major restrictions on fertilizers and pesticides" (Stolze et al. [5]). The OPS is based on different crop farming practices, protection of the environment and promotion of sustainable agricultural development. It "pursues a number of aims, such as the production of products, which contain no chemical residues, the development of environmentally sensitive production methods, which avoid the use of artificial chemical pesticides and fertilizers, and the application of production techniques that restore and maintain soil fertility" (Stolze et al. [5]). In addition, OPS utilizes beneficial management practices which incorporate mitigation strategies for reducing GHG emissions (Scialabba [6]).

As OPS strives to combine tradition, innovation and science to benefit the shared environment and promote fair relationships and a good quality of life for all involved, an assessment of long-term environmental, economic, and social benefits relative to comparable conventional production system (CPS) is needed. Although the role of organic agriculture in mitigating GHG emissions is recognized, there may be some indirect impacts of converting crop area from CPS to OPS. For example, as demand for farm inputs contributing to GHG emissions (fertilizer and pesticides) decreases, some of the industries producing these inputs could be affected adversely. Ultimately this process may affect the level of regional economic development. Thus, a situation of trade-off between environmental protection and economic development may result from such a conversion. In Canada, there has been minimal research done on OPS's role in GHG mitigation or in identifying other benefits (or costs) to society. This study was undertaken to fill this void.

\section{Study methods}

\subsection{Literature review}

A review of studies indicates that there is wide agreement that OPS comes closest to an environmentally friendly agriculture. It is generally perceived as a form of agriculture that is more favorable for the environment than CPS. Abbas 
and Fares [7] suggest that OPS improves soil organic carbon and thus improves the soil structure, aggregation, fertility, water retention, and crop production. In addition, the OPS eliminates or reduces the use of many farm inputs required for CPS. Some example may include: the use of synthetic fertilizer, synthetic pest control mechanisms, among others. Niggli et al. [8] indicate that "organic agriculture reduces energy requirements for production systems by 25 to 50 per cent compared to conventional chemical-based agriculture." These changes could possibly make farming a carbon-neutral industry. Comparative studies of energy use show lower per unit-of-yield fossil fuel energy use in OPS relative to comparable CPS systems (Stolze et al. [5]). Pimentel et al. [9] estimated that fossil energy inputs for OPS corn were about 30\% lower than for CPS corn. In addition, Pimentel et al. [9] have reported that organic systems eliminate agrochemicals and reduce other external inputs to improve the environment and farm economics. Similar evidence has also been reported for German farms by Lotter et al. [11].

In Canada, Parsons and Williams [10] reported that organic production system protects the environment, minimizes soil degradation and erosion, decreases pollution, replenishes and maintains long-term soil diversity, and provides care that promotes the health and behavioural needs of animals. It is also reported that OPS can enhance biodiversity through enhanced richness of flora and fauna, as well as benefit habitat diversity and landscape value. Alföldi et al. [12] found that the diversity of landscapes and production systems is greater on organic farms than on conventional farms.

Kasterine and Niggli [13] show that organic farming is so far the most promising approach for mitigation and adaptation to climate change. By comparing OPS and CPS in global vision, Badgley et al. [14] found evidence that organic agriculture has the potential to contribute quite substantially to the global food supply, while reducing the detrimental environmental impacts of conventional agriculture. However, the principal objection to the proposition that organic agriculture can contribute significantly to the global food supply are low yields and insufficient quantities of organically acceptable fertilizers. Nonetheless Badgley et al. [14] have indicated that organic methods could produce enough food on a global per capita basis to sustain the current human population, and potentially an even larger population, without increasing the agricultural land base.

The OPS is well placed to support local and regional economies. It has been argued that organic farming can provide rural development benefits through enhanced employment and closer connections with the local economy and give rise to greater economic and socio-economic linkages within rural economies (Lobley et al. [15]). This system often requires more labour, thus providing rural jobs. The substitution of chemical inputs in organic agriculture generally results in higher demand for labour in comparison with CPS and therefore, should contribute to rural employment. Sumner [16] has concluded that in southwestern Ontario, organic farmers promote rural development by making a wide range of economic, social and environmental contributions. 


\subsection{Analytical framework for trade-off analysis}

As noted above, the major objective of this study was to undertake a Trade-off Analysis (TOA). This analysis was undertaken for the three Prairie Provinces of Canada - Manitoba, Saskatchewan, and Alberta - using four indicators: (1) mesoeconomic indicator of total physical production of crops (2) microeconomic indicator of farm level profitability, (3) environmental quality indicator of GHG emission levels, and (4) macroeconomic indicator of regional economic growth. An overview of the study methodology is shown in Figure 1.

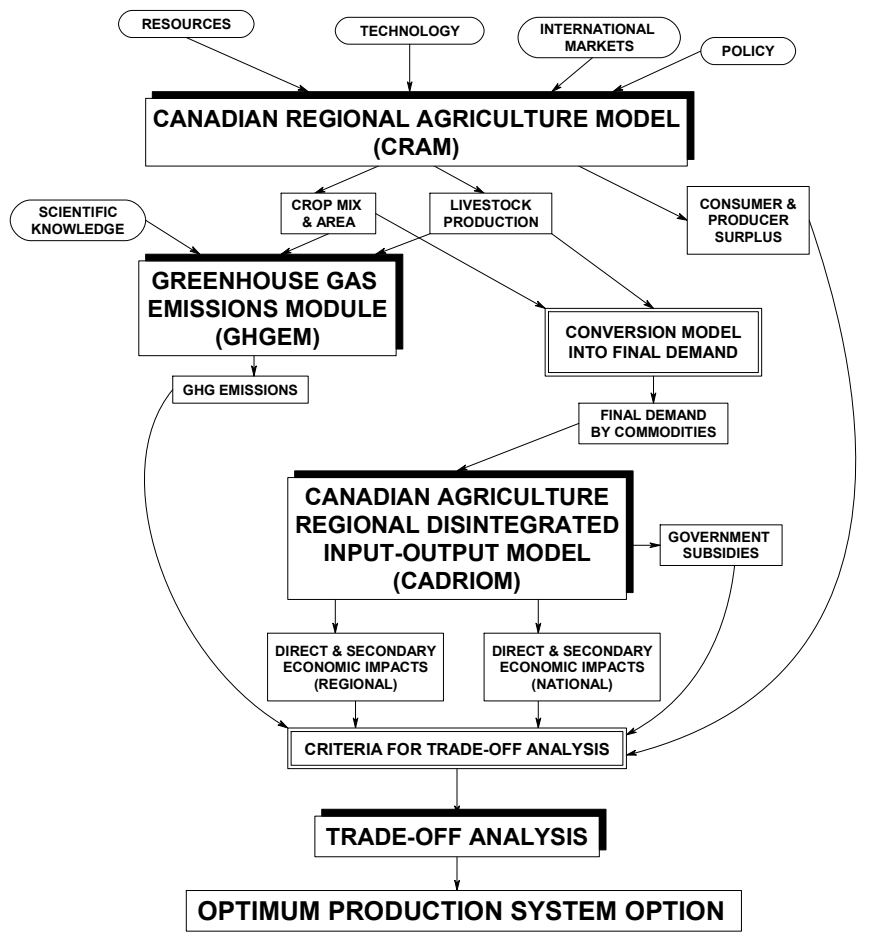

Figure 1: Overview of study methodology to determine optimal production system.

In order to estimate the above four indicator, three separate, but integrated models, were developed. These were: CRAM - Canadian Regional Agriculture Model (described in Kulshreshtha et al. [17]), GHGEM - Greenhouse Gas Emissions Model (described in Sobool and Kulshreshtha [18]), and CARDIOM - Canadian Regional Disaggregated Input-Output Model (described in Sobool and Kulshreshtha [19]). While undertaking the TOA, levels of GHG emissions from OPS and CPS were compared against other impacts that result from such a conversion. This comparison then became the basis for a decision to be made by society on the more socially desirable option to adopt. 
The crop rotation evaluated in this study was a six-year rotation, each crop grown once, as shown in Equation (1).

$$
\text { Alfalfa - Wheat - Barley - Flax - Oats - Peas }
$$

Since organic production is mainly confined to the Canadian Prairie Region (consisting of Manitoba, Saskatchewan, and Alberta), simulation of impacts of the conversion from CPS to OPS was undertaken for this region. In each of these provinces, a $10 \%$ of the cultivated area was subjected to this conversion, using equal share for each crop.

\subsection{Source of data}

For the purposes of this study, farm level data for CPS were obtained from CRAM files. These included yield and all major expenditures in the production of the above six crops in the rotation. Data for the OPS were obtained from the University of Saskatchewan [20] and Alberta Agriculture, Food, and Rural Development [21].

Total production indicator was simply a sum of physical quantities under the two systems, each of which was obtained as a product of area and its respective yield in each region. The farm level economic indicator was estimated as Net Farm Returns over Variable Costs. To calculate producer returns, prices were collected from Alberta Agriculture, Food, and Rural Development [21].

The environmental indicator - emissions of GHGs - was based on the area and cultural practices for each crop under each production system. The GHGEM was developed using IPCC Tier 3 methodology for various emission sources related to crop production. Total GHG emissions were converted into Carbon Dioxide Equivalent $\left(\mathrm{CO}_{2 \mathrm{E}}\right)$ using a global warming factor for each of the three major gases as: Carbon dioxide $=1$; Methane $=21$; and Nitrous Oxide $=310$.

The output of CRAM was also used to estimate regional economic activities in various Provinces using CARDIOM. This model estimates impact of the conversion on sectoral sales, gross domestic production of the region, household incomes, and employment levels. Since Canadian economy has open borders, interprovincial trade is a significant avenue for meeting local consumer and sector input demands. For this reason, the results for the Prairie region were used to estimate economic development impact for Canada as a whole. The difference between Canadian level impacts and the Prairie region impacts were attributed to inter-provincial trade.

\subsection{Assessment of trade-offs}

The TOA was undertaken from the accounting stance of Canada as a whole. The criteria used were: (1) total GHG emissions in $\mathrm{CO}_{2 \mathrm{E}}$ units; (2) farm level economic impact, as measured by net farm returns; (3) economic development impacts, as measured through change in gross domestic product at market prices; and (4) employment, as measured in number of jobs in full time equivalent. 


\section{Results}

Results for each of the four indictors used for the TOA are shown in this section. In each case, the presentation is in terms of marginal change - OPS minus CPS.

\subsection{Comparison of level of production impacts}

From the standpoint of a producer undertaking the conversion from CPS to OPS, the level of production available for sale (or for internal use on farm) is an important consideration. Total production comparisons are presented in table 1 for the three Prairie Provinces as a whole. As noted here, there is a decrease in the total amount (physical weight) of production triggered by this conversion. Excluding the bulky forage crops (which are grown for cattle production), there is a loss of almost 2 million tonnes of food products resulting from this conversion. High maintenance crops, such as flax and peas, with a weak ability to compete against weeds and other pests, put OPS at a major disadvantage. The lower yields under OPS are a result of no herbicides being used to control weed populations, increasing the crop competition.

Table 1: Net effect of conversion from CPS to OPS on crop output in the Prairie Provinces.

\begin{tabular}{|c|c|c|}
\hline Crop & $\begin{array}{c}\text { Area } \\
\text { Converted } \\
\text { ('000 Ha) }\end{array}$ & $\begin{array}{c}\text { Total Change (OPS - } \\
\text { CPS) in Production } \\
\text { in Thousand Tonnes }\end{array}$ \\
\hline Alfalfa & 1,304 & 160.26 \\
\hline Wheat & 968 & -253.20 \\
\hline Barley & 368 & -120.96 \\
\hline Oats & 212 & -23.79 \\
\hline Flax & 964 & -432.84 \\
\hline Field Peas & 1,400 & $-1,263.49$ \\
\hline Total Production excl. Alfalfa & & $-2,094.28$ \\
\hline
\end{tabular}

\subsection{Comparison of farm level economics}

Although OPS yields lower levels of production, organic producers are compensated through higher prices for their products. This premium is a reflection of lower availability of organic product due perhaps to lower production levels and higher willingness-to-pay by consumers for these products. Evaluating economic implications at the farm level requires analysis of two major elements: cost of production and gross revenue. Table 2 summarizes the differences in total on-farm returns under the two systems. The higher returns and lower input costs of OPS outweigh the total production benefit associated with CPS. Although field peas are marginally profitable in Saskatchewan, such is not the case in Alberta and Manitoba, thereby reducing overall returns to producers in the region. Here field pea price premiums do not compensate for 
the reduction in yields. In total, Prairie producers are better off by $\$ 756$ million by following the study rotation and converting production systems from CPS to OPS.

Table 2: Total on-farm returns from converting cropland from CPS to OPS by province and crop, 2000 (OPS minus CPS).

\begin{tabular}{|c|c|c|}
\hline Crop & Amount in Million $\$$ & Amount $\$ \mathrm{ha}^{-1}$ \\
\hline Alfalfa & $\$ 6.34$ & $\$ 4.86$ \\
\hline Feed Barley & $\$ 210.91$ & $\$ 217.88$ \\
\hline Wheat & $\$ 149.46$ & $\$ 406.14$ \\
\hline Oats & $\$ 60.15$ & $\$ 283.73$ \\
\hline Flax & $\$ 350.51$ & $\$ 363.60$ \\
\hline Field Peas & $-\$ 21.09$ & $-\$ 15.06$ \\
\hline Total Farm Returns & $\$ 756.28$ & $\$ 144.99$ \\
\hline
\end{tabular}

\subsection{Comparison of GHG emissions}

Converting farm land under a CPS to OPS in the Canadian Prairie Provinces reduces the total GHG emission associated with crop production. Results are shown in table 3. GHG are emitted from numerous activities directly and indirectly related to crop production, as listed in the table.

Table 3: Reduction in Greenhouse Gas Emission Resulting from Conversion of Crop Production (CPS minus OPS), By Source.

\begin{tabular}{|c|c|c|}
\hline Source & $\begin{array}{c}\text { GHG Emissions in } \\
\text { kilo tonnes* of } \mathrm{CO}_{2 \mathrm{E}}\end{array}$ & Percent of Total \\
\hline Direct Crop Production & 1244.00 & $47.1 \%$ \\
\hline Indirect Emissions & 379.77 & $14.4 \%$ \\
\hline Fuel for Crop & 92.76 & $3.5 \%$ \\
\hline On-Farm & 26.44 & $1.0 \%$ \\
\hline Sub-Total farm Level & $1,742.97$ & $66.0 \%$ \\
\hline $\begin{array}{c}\text { Farm Input Production, } \\
\text { Transportation and } \\
\text { Storage }\end{array}$ & 767.93 & $29.1 \%$ \\
\hline Off-farm & 131.35 & $5.0 \%$ \\
\hline Sub-Total Off-farm & 899.28 & $34.0 \%$ \\
\hline Total GHG Emissions & $2,642.25$ & $100.0 \%$ \\
\hline
\end{tabular}

* Equivalent to one Giga Gram

For crop production, the primary source of $\mathrm{CO}_{2}$ is the burning of fossil fuels for stationary combustion, and that for nitrous oxide is use of fertilizer for CPS. Estimates in table 3 suggest that under the assumed conversion, a reduction of 
2.64 Mt of GHG emissions is estimated. These emissions mainly come from direct use of fertilizer (included under Direct Crop production), and indirect emissions and manufacturing of fertilizer are also responsible for $0.77 \mathrm{Mt}$ of GHG emissions.

On a per unit of land basis, OPS emits only $621 \mathrm{~kg} \mathrm{ha}^{-1}$, where as the CPS emits $1,128 \mathrm{~kg} \mathrm{ha}^{-1}$. This is a $44.9 \%$ reduction in the total GHG emissions (table 4). As shown in Figure 2, much of the reduction is through nitrous oxide, which constitutes $63 \%$ of the total GHG emissions.

Table 4: Comparison of GHG emissions (in carbon dioxide equivalent) on a per hectare basis from CPS to OPS, Canadian Prairies.

\begin{tabular}{|c|c|}
\hline Particulars & GHG Emissions in $\mathrm{kg} \mathrm{ha}^{-1}$ \\
\hline Conventional Production System & 1,128 \\
\hline Organic Production System & 621 \\
\hline $\begin{array}{c}\text { Difference (Organic - } \\
\text { Conventional) }\end{array}$ & -507 \\
\hline $\begin{array}{c}\text { \% Change from Conventional } \\
\text { Production System }\end{array}$ & $44.9 \%$ \\
\hline
\end{tabular}

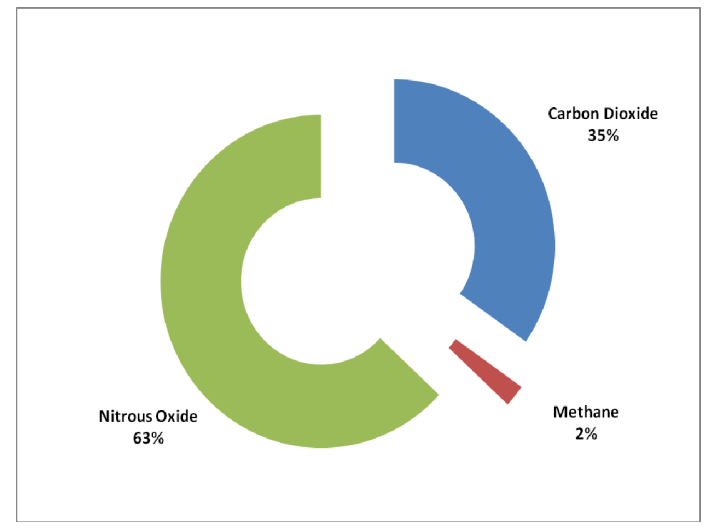

Figure 2: Distribution of reduction from conversion from conventional to organic production system.

\subsection{National and regional economic development impacts}

Direct impacts of conversion from conventional to organic production system are only a part of the total impact on the economy. Production of agricultural commodities in the Prairies generates many spin-off effects in these provinces, as well as in other parts of Canada. Changing the make-up of the way in which regional activities interact will ultimately change the overall regional economic development. Table 5 shows these results for the three Prairie Provinces, for other parts of Canada, and for Canada as a whole. These results suggest that there will be an increase in GDP (in market prices), household income and 
employment in all three Prairie Provinces as a result of the conversion. Canada as a whole will also see gains in GDP, household income and employment, while regions of Canada outside the Prairie Provinces will see some negative impacts on employment level. Due to the conversion of the cropland, another $\$ 200$ million in household incomes, \$345 million in GDP, and there is an estimated additional 6,722 (fulltime equivalent) jobs across the Prairie Provinces. However, for Canada has a whole, a net gain in full-time equivalent is lower at 6,606 jobs.

Table 5: Regional economic impact of conversion of 10 per cent of cropland in the Prairie provinces on the Canadian economy, by economic indicators, and by regions, $2000 \$$.

\begin{tabular}{|c|c|c|c|c|}
\hline Type of Impact & Unit & $\begin{array}{c}\text { Prairie } \\
\text { Provinces }\end{array}$ & $\begin{array}{c}\text { Rest of } \\
\text { Canada }\end{array}$ & $\begin{array}{c}\text { Total } \\
\text { Canada }\end{array}$ \\
\hline $\begin{array}{c}\text { Change in Sales of } \\
\text { Various Sectors }\end{array}$ & Million \$ & 634.7 & 118.2 & 752.9 \\
\hline GDP at market Prices & Million \$ & 344.8 & 37.6 & 382.4 \\
\hline Household Income & Million \$ & 200.5 & 59.2 & 259.7 \\
\hline Employment & Full-time Jobs & 6,722 & -116 & 6,606 \\
\hline
\end{tabular}

\subsection{Trade-off analysis}

Evaluation of the trade-offs that result from farmers adopting OPS in the prairies was accomplished by taking into account the four indicators: GHG emissions, net farm income, economic development, and employment. The TOA was undertaken from a national perspective. Results are shown in Figure 3. Under

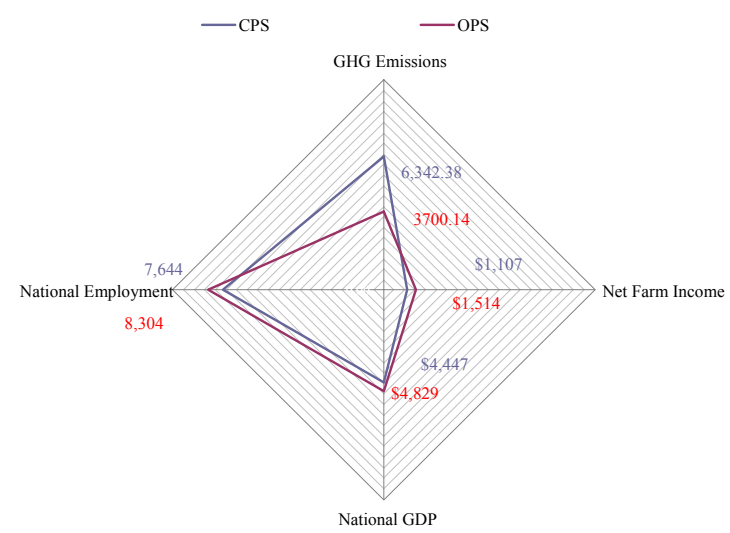

Trade-off Analysis: GHG emissions (kilo tonnes), Net Farm Income (\$ million), regional GDP (\$ millions) and employment (1/10)

Figure 3: Radar diagram: trade-off analysis of conversion of cropland from CPS to OPS. 
this accounting stance, conversion of CPS to OPS is supported both on economic and environmental grounds. Here the GHG emissions are reduced for the country, the net farm income improves, and the national GDP and employment increases. The above results are under the present situation of a lack of market for selling carbon credits. However, if such a trading mechanism was in place and a value of carbon could be established, this would provide additional economic incentive, on a national as well as regional basis, to encourage such a conversion.

\section{Conclusion}

Conversion of land under a CPS to OPS was generally positive for both the Prairie Provinces and for Canada as a whole. GHG emissions were reduced by 2.64 mega tonnes of $\mathrm{CO}_{2 \mathrm{E}} \mathrm{yr}^{-1}$ (amounting to $507 \mathrm{~kg} \mathrm{ha}^{-1} \mathrm{yr}^{-1}$ ) generating a major environmental benefit. Net farm income was estimated to increase by $\$ 260$ million, whereas the Canadian GDP was estimated to increase by $\$ 382$ million. Employment levels were estimated to increase by 6,722 full time equivalents in the Prairie Provinces. This was primarily in the grains and oilseed sector and related industries. There was a significant decline in total crop production for nearly all crops. In spite of this decrease, net farm income levels were offset through higher prices for organic products. These results suggest that conversion of agricultural land from conventional to organic agriculture would be a win-win proposition for Canada.

Because of the scope of the project, a number of limitations of the study can be identified. First, producers following either conventional or organic production system have a choice of a number of different crop rotations. This study evaluates a single crop rotation. This may have limited the ability to examine potential production and economic returns under alternate conditions. Second, organic markets continue to fluctuate over time. It is difficult to predict what the future of the market will be for organic products. Demand will influence price and increased production around the world may decrease the premiums on these products obtained by producers. A forecast of such demand and its use in future analysis deserves mentioning, but was deemed unusable for the current analysis. Third, this study compared the production system under the two practices. There may also be differences at the processing and related activities between commodities produced under conventional and organic production system. This may need further examination.

\section{References}

[1] Hanley, N., Introduction, pp. 3-11. Farming and the Countryside - An Economic Analysis of External Costs and Benefits, ed. N. Hanley. Wallingford, Oxon, UK: CAB International, 1991.

[2] IPCC - Intergovernmental Panel on Climate Change, Climate Change 1995: The Science of Climate Change. Great Britain: Cambridge University Press. 1996. 
[3] Rosenberg, N., Cole, C., \& Paulstain, K., Mitigation of Greenhouse Gas Emissions by the Agriculture Sector. Climate Change. 40, pp. 1-5, 1998.

[4] Government of Canada, Government of Canada Action Plan 2000 on Climate Change. Online. http://www.cquest.utoronto.ca/env/env200y/ ESSAY2001/gofcdaplan_eng2.pdf. 2000.

[5] Stolze, M., Piorr, A., Haring, A., \& Dabbert, S., The Environmental Impacts of Organic Farming in Europe. Organic Farming in Europe: Economics and Policy 6. pp. 389-96, 2000.

[6] Scialaba, N., Organic Agriculture and Biodiversity. Food and Agriculture Organization. Online.

http://www.fao.org/organicag/doc/soil_biodiversity.htm. 2000.

[7] Abbas, F. \& Fares A., Soil Organic Carbon and Carbon Dioxide Emission from an Organically Amended Hawaiian Tropical Soil. Soil Science Society of America Journal, 73(6), pp. 2118-2130, 2008.

[8] Niggli, U., Fließbach, A., Hepperly, P. \& Scialabba, N., Low Greenhouse Gas Agriculture: Mitigation and Adaptation Potential of Sustainable Farming Systems. FAO, Rome, 2009.

[9] Pimentel, D., Hepperly, P., Hanson, J. Douds, D., Seidel, R. (2005): Environmental, energetic, and economic comparisons of organic and conventional farming systems. BioScience 55 (7), Pages 573-582.

[10] Parsons, Williams, 2002. Organic fruit and vegetable production: Is it for you? Statistics Canada. Ottawa Canada. Online. http://www.statcan.gc.ca/pub/21-004-x/21-004-x2002009-eng.pdf. 2002.

[11] Lotter, D., Seidel, R., \& Liebhardt, W., The performance of organic and conventional cropping systems in an extreme climate year. Amer. Jour of Alt Agriculture 18(2), pp. 1-9, 2003.

[12] Alföldi, T, Fließach, A., Geier, U., Kilcher, L., Niggli, U., Pfiffner, L., Stolze, M. \& Wiler, H., Organic agriculture and the environment. Organic Agriculture, Environment and Food Security, ed. In: N. E. H. Scialabba, and C. Hattum, Food and Agriculture Organization of the United Nations, Rome. 2002.

[13] Kasterine, A. \& Niggli, U., Organic Farming and Climate Change. International Trade Centre UNCTAD/WTO. Online. http://www.ifoam.org/growing_organic/1_arguments_for_oa/environmental benefits/pdfs/FiBLStudyOrganic_Farming_and_Climate_Change.pdf. 2007.

[14] Badgley, C., Moghtader, J., Quintero, E., Zakem, E., Chappell, M.J., vilesVazquez, K., Samulon, A., \& Perfecto, I., Organic agriculture and the global food supply. Renewable Agriculture and Food Systems 22, pp. 86-108, 2007.

[15] Lobley, M., Butler, A., \& Reed, M., The contribution of organic farming to rural development: An exploration of the socio-economic linkages of organic and non-organic farms in England. Land Use Policy, 26(3), pp. 723-735, 2009.

[16] Sumner, J., Organic farmers and rural development. Research report on the links between organic farmers and community sustainability in 
southwestern Ontario. Online. http://www.organicagcentre.ca/DOCs/org farmers_rural_dev.pdf. 2005.

[17] Kulshreshtha, S., Gill, R., Junkins, B., Desjardins, R., Boehm, M. \& Bonneau, M., Canadian Economic and Emissions Model for Agriculture (C.E.E.M.A. 2.0): Technical Documentation. Saskatoon: Center for Studies in Agriculture, Law and the Environment. 2002.

[18] Sobool, D. \& Kulshreshtha, S., Greenhouse Gas Emissions from Canadian Agriculture Model.(2000): Technical documentation (GHGEM). Saskatoon: Department of Agricultural Economics University of Saskatchewan, 2005.

[19] Sobool, D. \& Kulshreshtha, S., Canadian Agriculture Regional Disaggregated Input-Output Model. Research Report. Saskatoon: Department of Agricultural Economics, University of Saskatchewan, 2006.

[20] University of Saskatchewan, 2005. Organic Crop Planning Guide. Online. http://organic.usask.ca/cropplanning.htm.

[21] AAFRD - Alberta Agriculture, Food, and Rural Development, 2001. Organic Grain and Oilseed Enterprise. Online. http://www1.agric.gov.ab.ca/\$department/deptdocs.nsf/all/agdex3630. 